\title{
Gene mutations in Cushing's disease (Review)
}

\author{
QI XIONG ${ }^{1,2}$ and WEI GE ${ }^{1}$ \\ ${ }^{1}$ National Key Laboratory of Medical Molecular Biology and Department of Immunology, \\ Institute of Basic Medical Sciences, Chinese Academy of Medical Sciences, Beijing 100005; \\ ${ }^{2}$ Department of Orthopedics, General Hospital of Chinese PLA, Beijing 100853, P.R. China
}

Received March 22, 2016; Accepted June 17, 2016

DOI: $10.3892 /$ br.2016.729

\begin{abstract}
Cushing's disease (CD) is a severe (and potentially fatal) disease caused by adrenocorticotropic hormone (ACTH)-secreting adenomas of the pituitary gland (often termed pituitary adenomas). The majority of ACTH-secreting corticotroph tumors are sporadic and CD rarely appears as a familial disorder, thus, the genetic mechanisms underlying $\mathrm{CD}$ are poorly understood. Studies have reported that various mutated genes are associated with $\mathrm{CD}$, such as those in menin 1, aryl hydrocarbon receptor-interacting protein and the nuclear receptor subfamily 3 group $\mathrm{C}$ member 1 . Recently it was identified that ubiquitin-specific protease 8 mutations contribute to $\mathrm{CD}$, which was significant towards elucidating the genetic mechanisms of $\mathrm{CD}$. The present study reviews the associated gene mutations in CD patients.
\end{abstract}

\section{Contents}

\section{Introduction}

2. Menin $1(M E N 1)$ mutation

3. Nuclear receptor subfamily 3 group $\mathrm{C}$ member 1 (NR3Cl) mutation

4. Aryl hydrocarbon receptor-interacting protein $(A I P)$ mutation

5. Tumor protein p53 (TP53) mutation

6. Nuclear receptor subfamily 0 group B member 1 (NROBI) mutation

7. Ubiquitin-specific peptidase 8 (USP8) mutation

8. Dicer 1, ribonuclease III (DICERI) mutation

9. Cytochrome $\mathrm{P} 450$ family 21 subfamily A member 2 (CYP21A2) mutation

10. GNAS complex locus (GNAS) mutation

Correspondence to: Dr Wei Ge, National Key Laboratory of Medical Molecular Biology and Department of Immunology, Institute of Basic Medical Sciences, Chinese Academy of Medical Sciences, 5 Dongdansantiao, Beijing 100005, P.R. China

E-mail: wei.ge@chem.ox.ac.uk

Key words: Cushing's disease, adrenocorticotropic hormone, pituitary adenomas, gene mutation
11. Leukemia inhibitory factor $(L I F)$ mutation and cyclin-dependent kinase inhibitor $1 \mathrm{~B}(C D K N 1 B)$ mutation 12. Conclusions

\section{Introduction}

Cushing's disease (CD) is a severe (and potentially fatal) disease caused by adrenocorticotropic hormone (ACTH)-secreting adenomas of the pituitary gland [often termed pituitary adenomas (PAs)], and constitutes $10-15 \%$ of all PAs worldwide (1). Excess secretion of ACTH in CD results in the following symptoms: Central obesity, hirsutism, glucose intolerance and osteoporosis. Since their first description in 1932 (2), the pathogenesis of tumors of the pituitary gland has not been elucidated, which has hindered the early diagnosis of many cases of PA.

Generally, PAs result from clonal expansion of somatic mutated cells (3). Studies have suggested that $40 \%$ of sporadic PAs are associated with somatic mutations of genes (4). Germline mutations in genes also predispose individuals to PAs (5). Thus, tumorigenesis in the pituitary gland may be explained by gene mutation.

Recent studies have demonstrated that mutations in the aryl hydrocarbon receptor-interacting protein $(A I P)$ gene, and Carney complex and multiple endocrine neoplasia type 1 (MEN1) are associated with sporadic PAs $(6,7)$. Disruption in the balance of pituitary-secreting hormones as a result of gene mutation may result in severe-to-fatal consequences. Therefore, identification of relevant gene mutations is particularly useful in the early diagnosis of CD, and for genetic counseling of CD patients.

It has been suggested that CD may be a consequence of hereditary disease (8). Previous studies revealed genetic factors to be involved in CD $(9,10)$. Recently, a review by Perez-Rivas and Reincke (11) specified the roles of mutations in ubiquitin-specific protease 8 (USP8) in CD. In the present study, the gene mutations that have been reported in $C D$ patients are reviewed.

\section{Menin 1 (MEN1) mutation}

MEN1 is composed of 10 exons, is located in chromosome $11 \mathrm{q} 13$ and encodes a 610 -amino acid menin protein. Bassett et al (12) identified 47 mutations in the coding exons 
of MEN1 as follows: 12 Nonsense mutations, 21 deletions, 7 insertions, 1 donor splice-site mutation and 6 missense mutations. The authors suggested that $80 \%$ of these mutations were likely to be inactivating (12). Mutations in MEN1 have been found to be associated with pancreatic endocrine tumors (13). Furthermore, inactivating mutations of $M E N 1$ lead to a familial disorder termed MEN1, of which one common component is CD (14). Thus, it has been speculated that mutations in MEN1 may also participate in CD. Stratakis et al (5) reported that two mutations of MEN1 (a deletion mutation and p.Arg415X) were identified in $\mathrm{CD}$ patients. Matsuzaki et al (15) reported an R460X mutation in MEN1 in a Brazilian subject with early-onset $\mathrm{CD}$ and his sister. A heterozygote $\mathrm{C} \rightarrow \mathrm{T}$ transition was detected at codon 460 in exon 10 in $M E N 1$, which converts codon 460 CGA (Arg) to a stop codon TGA (15). Thus, mutations in $M E N 1$ lead to the early clinical manifestations of MEN1, and are involved in CD. Furthermore, these findings confirm the hereditary characteristics of CD.

\section{Nuclear receptor subfamily 3 group $\mathrm{C}$ member 1 (NR3C1) mutation}

Perfect balance in the requirement and secretion of glucocorticoid hormones (which is maintained by feedback from the hypothalamic-pituitary-adrenal-axis) is critical for the regulation of glucose metabolism and the feedback mechanism in the immune system.

CD patients share the characteristics of resistance to glucocorticoids and unresponsiveness to normal glucocorticoid negative feedback (16). However, somatic mutations of $\mathrm{NR} 3 \mathrm{Cl}$, or dysfunction of genes associated with glucocorticoid receptor function, are rarely found in CD (5). However, Karl et al (10) reported a novel heterozygous missense mutation in $\mathrm{NR} 3 \mathrm{Cl}$ in a $C D$ patient. The authors found that the mutation occurs in exon 5 of the coding region of $N R 3 C 1$ in lymphoblasts and fibroblasts, as well in $50 \%$ of sperm. As a result, the neutral and polar asparagine at codon 559 substitutes the neutral and hydrophobic amino acid, isoleucine. The authors also suggested that the mutation contributed to severe, sporadic, generalized glucocorticoid resistance. Further investigation demonstrated that the mutation was not detected in the patient's parents or seven siblings. Therefore, it was concluded that this novel mutation was de novo and present in the germline (10). That is, the mutation in NR3C1 may be involved in CD.

\section{Aryl hydrocarbon receptor-interacting protein $(A I P)$ mutation}

AIP is a protein of 330 amino acids and acts as a tumor suppressor (17). Studies have demonstrated that AIP combines with the aryl hydrocarbon receptor on the cell surface, and probably exerts its effects by regulating integrin function. More than 100 variants in AIP have been identified, of which the most frequent mutation occurs in the p.R304 locus (18). Approximately $15-30 \%$ of familial isolated PAs harbor germline mutations in $A I P(19,20)$. PAs with mutations in $A I P$ are predominantly somatotropinomas and prolactinomas; however, studies have revealed that AIP mutations may also occur in CD. Georgitsi et al (9) found a heterozygous c.696G $>C$ (which leads to the silencing of p.P232P in exon 5) in a CD patient in Poland. Furthermore, Stratakis et al (5) reported a novel germline AIP mutation, c.308A>G/p.Lys103Arg, in the heterozygotic state in one pediatric patient with recurrent $C D$, although the authors suggested that the overall prevalence of AIP mutation was very low. These findings indicate that AIP mutations may be directly involved in the molecular pathogenesis of $\mathrm{CD}$, but that screening for mutations may not be an effective method for the diagnosis of CD.

\section{Tumor protein p53 (TP53) mutation}

The $\mathrm{p} 53$ protein is encoded by a tumor-suppressor gene termed TP53, which is located on chromosome 17.p53 inhibits the $\mathrm{G}_{1} \rightarrow \mathrm{S}$ transition of the cell cycle, and is significant in suppression of tumorigenesis. Studies have suggested that TP53 mutations are associated with the pathogenesis of $\sim 50 \%$ of human cancers, including those in the central nervous system $(21,22)$. However, the role of p53 in tumors of the pituitary gland is controversial. Oliveira et al (23) demonstrated p53 protein to be positive in only two of 148 PA patients, suggesting that p53 may not be a biomarker for tumors of the pituitary gland. Other studies have indicated that p53 expression in tumors of the pituitary gland cannot be detected, including ACTH-secreting adenomas (24-26). By contrast, Buckley et al (27) found that abnormal expression of p53 was involved in the development of invasive pituitary tumors. The common alterations associated with TP53 in human tumors are inactivating mutations, which occur between exon 5 to 8 (28). Levy et al (29) and Herman et al (30) failed to identify mutations in TP53 in PAs, although Kawashima et al (31) reported that a somatic mutation of TP53 contributed to a case of atypical PA that caused CD. The authors sequenced the region of exon 5 through to exon 8 of TP53 and identified a missense mutation of CTG>CGG on codon 145 (L145R). The study indicated that the mutation was detected in tumor tissues, but not in peripheral blood (31). These studies imply that a somatic mutation of TP53 may contribute to the pathogenesis of CD.

\section{Nuclear receptor subfamily 0 group $B$ member 1 (NROB1) mutation}

Dosage-sensitive sex reversal, adrenal hypoplasia critical region, on chromosome $X$, gene 1 (DAX-1) is critical in steroidogenic development and sex determination. Studies have demonstrated that DAX-1 suppresses the transcription of various genes expressed in the adrenal cortex and hypothalamic-pituitary-gonadal axis, such as steroidogenic factor-1 $(32,33)$. DAX-1 is encoded by NROB1, which comprises two exons separated by a $3.4-\mathrm{kb}$ intron. Studies have shown involvement of mutations of NROBl in hypogonadotropic hypogonadism and X-linked adrenal hypoplasia congenital $(34,35)$. However, the role of DAX-1 in ACTH-secreting PAs remains poorly understood. Suzuki et al (36) analyzed the regulatory mechanisms of differentiation of pituitary cells in 89 corticotroph adenomas. DAX-1 was found to be positive in all subjects, indicating that DAX-1 is essential for the genesis of ACTH-secreting PAs. Furthermore, De Menis et al (37) described a novel mutation of NROB1 in a patient with ACTH-secreting PA and X-linked adrenal hypoplasia congenita and his mother [a 4-bp insertion 
(AGCG) at nucleotide 259 in exon 1 of NROB1] leading to premature termination of transcription. This evidence indicates that monitoring of mutations in NROB1 may be beneficial for early diagnosis in patients with CD and X-linked adrenal hypoplasia congenita.

\section{Ubiquitin-specific peptidase 8 (USP8) mutation}

USP8 is a member of the USP family. The specific roles of USP 8 mutations in $\mathrm{CD}$ have been reviewed by Perez-Rivas and Reincke (11). Here, three studies published recently, which reported mutations of USP 8 in $\mathrm{CD}$, are reviewed.

Reincke et al (38) found that mutations of p.Ser718Cys, p.Pro720Arg and p.Ser718del in the 14-3-3 protein binding motif promoted the proteolytic cleavage and catalytic activity of USP8, which inhibited epidermal growth factor receptor (EGFR) degradation and prolonged EGF signaling, resulting in increased activity in the proopiomelanocortin (POMC) promoter and transcription, as well as causing CD. Perez-Rivas et al (39) demonstrated that somatic mutations comprising p.718Ser $>$ Pro, Ser718del, p.720Pro $>$ Gln, and p.720Pro $>$ Arg in USP8 diminished EGFR ubiquitination and induced the activity of the POMC promoter. Ma et al (40) reported the significant clinical relevance of three somatic mutations (c.CTC2151-2153del/p.S718del, c.C2159G/p. P720R and c.T2152C/p.S718P) of USP8 and CD. It was revealed that mutations in exon 14 of USP 8 disrupt the interaction between USP8 and 14-3-3 protein, leading to protection of the EGFR from lysosomal degradation. Mutations in USP8 sustain EGFR-mitogen-activated protein kinase signaling to promote ACTH production in CD (40). These findings clearly demonstrate that mutations in USP 8 contribute to $\mathrm{CD}$.

\section{Dicer 1, ribonuclease (RNase) III (DICERI) mutation}

DICER 1 is a highly conserved RNase III enzyme, the functions of which are predominantly associated with RNA interference pathways, including the processing of microRNA precursors into mature microRNAs $(41,42)$. DICER 1 is associated with various tumors, such as pulmonary adenomas and pleuropulmonary blastomas $(41,43)$. Hill et al $(44)$ suggested that almost all patients with pleuropulmonary blastoma exhibit germline mutations of DICER1. In addition, mutations in DICERI are involved in the development of cystic nephroma (45). As mutated DICERI participates in diverse types of tumors, previous studies have indicated that DICER 1 mutations result in tumors of the pituitary gland. Wildi-Runge et al (46) reported a germline heterozygous DICER 1 mutation in a blastoma of the pituitary gland in an infant, suggesting a role for DICER 1 mutations in tumors of the pituitary gland. Furthermore, Sahakitrungruang et al (47) described two novel DICER 1 mutations in a one-year-old female with a blastoma of the pituitary gland presenting with $\mathrm{CD}$. The results showed that a novel heterozygous c.3046delA (p.S1016VfsX1065) mutation in DICERl was identified by whole-exome sequencing of leukocytes and pituitary blastoma tumor tissues, and another somatic missense c.5538A->T (p.E1813V) mutation was identified in tumor tissues only (47). These findings indicate that DICER1 mutations may facilitate with understanding the pathogenesis of CD.

\section{Cytochrome P450 family 21 subfamily A member 2 (CYP21A2) mutation}

CYP21A2 encodes active steroid 21-hydroxylase enzyme. Studies have suggested that 21-hydroxylase-deficient mice show failure of inhibition of the hypothalamic-pituitary-adrenal axis (48). Mutations in CYP21A2 are responsible for congenital adrenal hyperplasia $(\mathrm{CAH})$, which is associated with CD in certain cases. Haase et al (49) found that a homozygous mutation in exon 7 of CYP21A2 (CTG>TTG, p.V281L) may have contributed to $\mathrm{CD}$ in a female patient with $\mathrm{CAH}$. Boronat et al (50) reported that a 39-year-old female patient with an ACTH-producing PA carried two point mutations in CYP21A2: A severe splicing 655G mutation at intron 2 and a mild V28L mutation at exon 7. Concurrently, a severe 8-bp deletion mutation was found at exon 3 of the CYP21A2 gene, which caused the 21-hydroxylase deficiency, in a 21-year-old CD patient (50). Although 21-hydroxylase deficiency is rarely observed in CD patients, CYP21A2 mutations may (at least in part) contribute to $\mathrm{CD}$.

\section{GNAS complex locus $(G N A S)$ mutation}

GNAS1 (also termed gsp oncogene) comprises 13 exons and is located on chromosome 20q13. GNAS encodes various proteins, including the $\alpha$ subunit of the stimulatory G protein (Gs $\alpha$ ), extra-large $\alpha$ s and 55-kDa neuroendocrine secretory protein. The activating and inactivating mutations of GNAS have previously been identified $(51,52)$. GNAS mutations have been found to be involved in certain endocrine diseases. Patten et al (53) demonstrated that the $\mathrm{A} \rightarrow \mathrm{G}$ point mutation in GNAS (which causes reduced immunoactivity in the Gs $\alpha$ protein) is associated with Albright's hereditary osteodystrophy. Other studies have reported that $40 \%$ of patients with functional PAs exhibit somatic mutations of GNAS, which often occur at codons R201 and Q227. Williamson et al (54) identified mutations of $\mathrm{CAG} \rightarrow \mathrm{CGG}$ and $\mathrm{CAG} \rightarrow \mathrm{CAC} / \mathrm{T}$ at codon $\mathrm{Q} 227$ in only two of 32 ACTH-secreting PAs, and suggested that these mutations are an uncommon abnormality in CD. Riminucci et al (55) observed an R201H mutation of GNAS in a child with CD, thereby extending the disease spectrum of the R201 mutation of GNAS. Therefore, an association between GNAS mutations and $\mathrm{CD}$ may improve the understanding of $\mathrm{CD}$ pathogenesis.

\section{Leukemia inhibitory factor (LIF) mutation and cyclin-dependent kinase inhibitor $1 \mathrm{~B}(C D K N 1 B)$ mutation}

LIF is the most pleiotropic member of the interleukin-6 family. LIF is essential in activation of the hypothalamo-pituitary-adrenal axis during inflammation (51). In LIF knockout mice, the ACTH response to stress is reduced, whereas LIF overexpression in transgenic mice leads to corticotroph cell hyperplasia and hypercortisolism $(56,57)$. LIF exerts a regulatory function by binding to the LIF receptor (LIF-R) and gp130 (58). These studies indicate that LIF promotes ACTH secretion, and that mutations in LIF- or LIF-R-encoding genes may contribute to $\mathrm{CD}$ pathogenesis. However, 


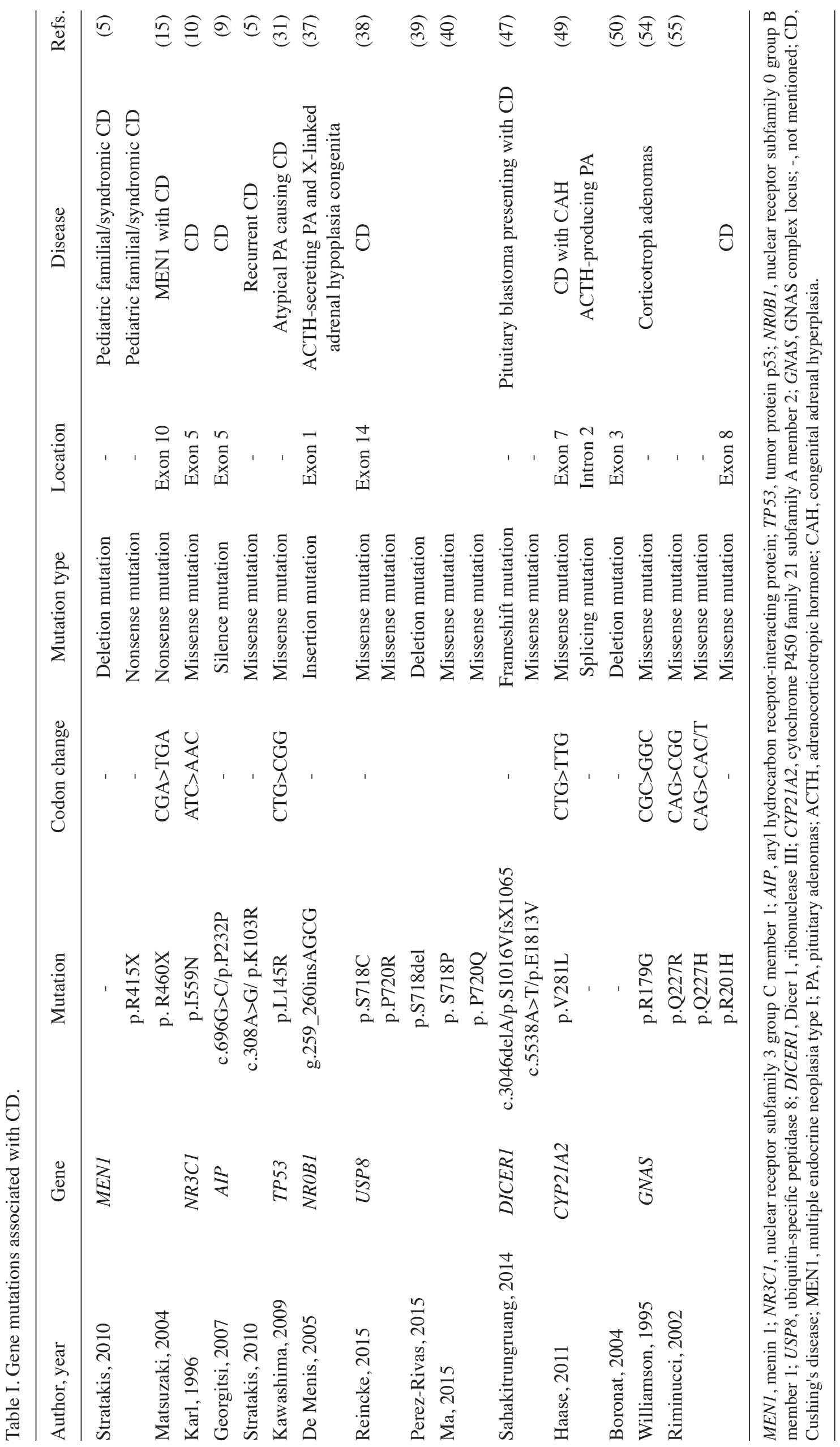


Heutling et al (59) did not observe mutations in LIF-R in ACTH-secreting adenomas, and suggested that mutations in LIF-R were an unlikely cause for CD development (59).

$C D K N 1 B$, also known as MEN4 and p27/kip1, maps to chromosome 12p13 and encodes a CDK inhibitor, which restricts cell cycle progression at $\mathrm{G}_{1}$. Lack of p27/kip1 function leads to the development of PAs (60). Furthermore, Liu et al (61) found that a selective inhibitor of CDK markedly suppressed ACTH levels and restrained growth of ACTH-secreting PAs in mice. One study revealed that germline $C D K N 1 B$ mutations rendered individuals more susceptible to MEN1 (62). Thus, it is speculated that $C D K N 1 B$ mutations may also participate in CD. However, Dahia et al (63) proposed that p27/kip1 mutations were not a feature of corticotroph tumors.

\section{Conclusions}

The majority of tumors of the pituitary gland appear to arise from a single mutated cell due to expansion of monoclonal cells. Therefore, distinct genetic changes are probably one of the most important events within tumorigenesis in the pituitary gland, including in ACTH-secreting corticotroph tumors. The current study reviewed previous investigations, which showed that various gene mutations are involved in CD (Table I). Cases are predominantly sporadic, therefore, the regulatory mechanisms of the gene mutations in $\mathrm{CD}$ are rarely investigated, although USP8 mutations have been more extensively evaluated. Thus, current treatment of CD patients has not progressed as a result of the identification of gene mutations that are associated with CD. However, the findings of the present review offer potential benefits regarding genetic counseling and early diagnosis of CD.

\section{Acknowledgements}

The present study was supported by the National Natural Science Foundation of China (grant no. 81373150).

\section{References}

1. Syro LV, Rotondo F, Ramirez A, Di Ieva A, Sav MA, Restrepo LM, Serna CA and Kovacs K: Progress in the diagnosis and classification of pituitary adenomas. Front Endocrinol (Lausanne) 6: 97, 2015.

2. Cushing H: The basophil adenomas of the pituitary body and their clinical manifestations (pituitary basophilism). 1932. Obes Res 2: 486-508, 1994.

3. Herman V, Fagin J, Gonsky R, Kovacs K and Melmed S: Clonal origin of pituitary adenomas. J Clin Endocrinol Metab 71: $1427-1433,1990$

4. Daly AF and Beckers A: Update on the treatment of pituitary adenomas: Familial and genetic considerations. Acta Clin Belg 63: 418-424, 2008

5. Stratakis CA, Tichomirowa MA, Boikos S, Azevedo MF, Lodish M, Martari M, Verma S, Daly AF, Raygada M, Keil MF, et al: The role of germline AIP, MEN1, PRKAR1A, CDKN1B and CDKN2C mutations in causing pituitary adenomas in a large cohort of children, adolescents, and patients with genetic syndromes. Clin Genet 78: 457-463, 2010.

6. Lecoq AL, Kamenický P, Guiochon-Mantel A and Chanson P: Genetic mutations in sporadic pituitary adenomas - what to screen for? Nat Rev Endocrinol 11: 43-54, 2015.

7. Daly AF, Jaffrain-Rea ML, Ciccarelli A, Valdes-Socin H, Rohmer V, Tamburrano G, Borson-Chazot C, Estour B, Ciccarelli E, Brue T, et al: Clinical characterization of familial isolated pituitary adenomas. J Clin Endocrinol Metab 91: 3316-3323, 2006.
8. Asa SL and Ezzat S: The pathogenesis of pituitary tumors. Annu Rev Pathol 4: 97-126, 2009.

9. Georgitsi M, Raitila A, Karhu A, Tuppurainen K, Mäkinen MJ, Vierimaa O, Paschke R, Saeger W, van der Luijt RB, Sane T, et al: Molecular diagnosis of pituitary adenoma predisposition caused by aryl hydrocarbon receptor-interacting protein gene mutations. Proc Natl Acad Sci USA 104: 4101-4105, 2007.

10. Karl M, Lamberts SW, Koper JW, Katz DA, Huizenga NE, Kino T, Haddad BR, Hughes MR and Chrousos GP: Cushing's disease preceded by generalized glucocorticoid resistance: Clinical consequences of a novel, dominant-negative glucocorticoid receptor mutation. Proc Assoc Am Physicians 108: 296-307, 1996.

11. Perez-Rivas LG and Reincke M: Genetics of Cushing's disease: An update. J Endocrinol Invest 39: 29-35, 2015.

12. Bassett JH, Forbes SA, Pannett AA, Lloyd SE, Christie PT, Wooding C, Harding B, Besser GM, Edwards CR, Monson JP, et al: Characterization of mutations in patients with multiple endocrine neoplasia type 1 . Am J Hum Genet 62: 232-244, 1998.

13. Wautot V, Vercherat C, Lespinasse J, Chambe B, Lenoir GM, Zhang CX, Porchet N, Cordier M, Béroud C and Calender A: Germline mutation profile of MEN1 in multiple endocrine neoplasia type 1: Search for correlation between phenotype and the functional domains of the MEN1 protein. Hum Mutat 20: 35-47, 2002.

14. Burgess JR, Greenaway TM and Shepherd JJ: Expression of the MEN-1 gene in a large kindred with multiple endocrine neoplasia type 1. J Intern Med 243: 465-470, 1998.

15. Matsuzaki LN, Canto-Costa MH and Hauache OM: Cushing's disease as the first clinical manifestation of multiple endocrine neoplasia type 1 (MEN1) associated with an R460X mutation of the MEN1 gene. Clin Endocrinol (Oxf) 60: 142-143, 2004.

16. Lamberts SW: Glucocorticoid receptors and Cushing's disease. Mol Cell Endocrinol 197: 69-72, 2002.

17. Vierimaa O, Georgitsi M, Lehtonen R, Vahteristo P, Kokko A, Raitila A, Tuppurainen K, Ebeling TM, Salmela PI, Paschke R, et al: Pituitary adenoma predisposition caused by germline mutations in the AIP gene. Science 312: 1228-1230, 2006.

18. Occhi G, Jaffrain-Rea ML, Trivellin G, Albiger N, Ceccato F De Menis E, Angelini M, Ferasin S, Beckers A, Mantero F, et al: The R304X mutation of the aryl hydrocarbon receptor interacting protein gene in familial isolated pituitary adenomas: Mutational hot-spot or founder effect? J Endocrinol Invest 33: 800-805, 2010.

19. Igreja S, Chahal HS, King P, Bolger GB, Srirangalingam U, Guasti L, Chapple JP, Trivellin G, Gueorguiev M, Guegan K, et al; International FIPA Consortium: Characterization of aryl hydrocarbon receptor interacting protein (AIP) mutations in familial isolated pituitary adenoma families. Hum Mutat 31: 950-960, 2010.

20. Leontiou CA, Gueorguiev M, van der Spuy J, Quinton R, Lolli F, Hassan S, Chahal HS, Igreja SC, Jordan S, Rowe J, et al: The role of the aryl hydrocarbon receptor-interacting protein gene in familial and sporadic pituitary adenomas. J Clin Endocrinol Metab 93: 2390-2401, 2008.

21. Levine AJ, Momand J and Finlay CA: The p53 tumour suppressor gene. Nature 351: 453-456, 1991.

22. Hollstein M, Sidransky D, Vogelstein B and Harris CC: p53 mutations in human cancers. Science 253: 49-53, 1991

23. Oliveira MC, Marroni CP, Pizarro CB, Pereira-Lima JF, Barbosa-Coutinho LM and Ferreira NP: Expression of p53 protein in pituitary adenomas. Braz J Med Biol Res 35: 561-565, 2002.

24. Sumi T, Stefaneanu L, Kovacs K, Asa SL and Rindi G: Immunohistochemical study of p53 protein in human and animal pituitary tumors. Endocr Pathol 4: 95-99, 1993.

25. Gandour-Edwards R, Kapadia SB, Janecka IP, Martinez AJ and Barnes L: Biologic markers of invasive pituitary adenomas involving the sphenoid sinus. Mod Pathol 8: 160-164, 1995.

26. Lübke D, Saeger W and Lüdecke DK: Proliferation markers and EGF in ACTH-secreting adenomas and carcinomas of the pituitary. Endocr Pathol 6: 45-55, 1995.

27. Buckley N, Bates AS, Broome JC, Strange RC, Perrett CW, Burke CW and Clayton RN: p53 Protein accumulates in Cushings adenomas and invasive non-functional adenomas. J Clin Endocrinol Metab 79: 1513-1516, 1994.

28. Copelli SB, Loza Coll MA and Bruno OD: Absence of mutations in the p53 tumor suppressor gene in non-invasive Cushing adenomas. Medicina (B Aires) 59: 459-462, 1999. 
29. Levy A, Hall L, Yeudall WA and Lightman SL: p53 gene mutations in pituitary adenomas: Rare events. Clin Endocrinol (Oxf) 41: 809-814, 1994.

30. Herman V, Drazin NZ, Gonsky R and Melmed S: Molecular screening of pituitary adenomas for gene mutations and rearrangements. J Clin Endocrinol Metab 77: 50-55, 1993.

31. Kawashima ST, Usui T, Sano T, Iogawa H, Hagiwara H, Tamanaha T, Tagami T, Naruse M, Hojo M, Takahashi JA, et al: P53 gene mutation in an atypical corticotroph adenoma with Cushing's disease. Clin Endocrinol (Oxf) 70: 656-657, 2009.

32. Reutens AT, Achermann JC, Ito M, Ito M, Gu WX, Habiby RL, Donohoue PA, Pang S, Hindmarsh PC and Jameson JL: Clinical and functional effects of mutations in the DAX-1 gene in patients with adrenal hypoplasia congenita. J Clin Endocrinol Metab 84: 504-511, 1999.

33. Nachtigal MW, Hirokawa Y, Enyeart-VanHouten DL, Flanagan JN, Hammer GD and Ingraham HA: Wilms' tumor 1 and Dax-1 modulate the orphan nuclear receptor SF-1 in sex-specific gene expression. Cell 93: 445-454, 1998.

34. Merke DP, Tajima T, Baron J and Cutler GB Jr: Hypogonadotropic hypogonadism in a female caused by an X-linked recessive mutation in the DAX1 gene. N Engl J Med 340: 1248-1252, 1999

35. Wu CM, Zhang HB, Zhou Q, Wan L, Jin J, Ni L, Pan YJ, Wu XY and Ruan LY: Two novel DAX1 gene mutations in Chinese patients with X-linked adrenal hypoplasia congenita: Clinical, hormonal and genetic analysis. J Endocrinol Invest 34 e235-e239, 2011.

36. Suzuki M, Egashira N, Kajiya H, Minematsu T, Takekoshi S, Tahara S, Sanno N, Teramoto A and Osamura RY: ACTH and alpha-subunit are co-expressed in rare human pituitary corticotroph cell adenomas proposed to originate from ACTH-committed early pituitary progenitor cells. Endocr Pathol 19: 17-26, 2008.

37. De Menis E, Roncaroli F, Calvari V, Chiarini V, Pauletto P, Camerino $\mathrm{G}$ and Cremonini N: Corticotroph adenoma of the pituitary in a patient with X-linked adrenal hypoplasia congenita due to a novel mutation of the DAX-1 gene. Eur J Endocrinol 153: 211-215, 2005

38. Reincke M, Sbiera S, Hayakawa A, Theodoropoulou M, Osswald A, Beuschlein F, Meitinger T, Mizuno-Yamasaki E, Kawaguchi K, Saeki Y, et al: Mutations in the deubiquitinase gene USP8 cause Cushing's disease. Nat Genet 47: 31-38, 2015.

39. Perez-Rivas LG, Theodoropoulou M, Ferraù F, Nusser C, Kawaguchi K, Stratakis CA, Faucz FR, Wildemberg LE, Assié G Beschorner R, et al: The gene of the ubiquitin-specific protease 8 is frequently mutated in adenomas causing Cushing's disease. J Clin Endocrinol Metab 100: E997-E1004, 2015.

40. Ma ZY, Song ZJ, Chen JH, Wang YF, Li SQ, Zhou LF, Mao Y, Li YM, Hu RG, Zhang ZY, et al: Recurrent gain-of-function USP8 mutations in Cushing's disease. Cell Res 25: 306-317, 2015

41. Bernstein E, Caudy AA, Hammond SM and Hannon GJ: Role for a bidentate ribonuclease in the initiation step of RNA interference. Nature 409: 363-366, 2001.

42. Grishok A, Pasquinelli AE, Conte D, Li N, Parrish S, Ha I, Baillie DL, Fire A, Ruvkun G and Mello CC: Genes and mechanisms related to RNA interference regulate expression of the small temporal RNAs that control C. elegans developmental timing. Cell 106: 23-34, 2001.

43. Chiosea S, Jelezcova E, Chandran U, Luo J, Mantha G, Sobol RW and Dacic S: Overexpression of Dicer in precursor lesions of lung adenocarcinoma. Cancer Res 67: 2345-2350, 2007

44. Hill DA, Ivanovich J, Priest JR, Gurnett CA, Dehner LP, Desruisseau D, Jarzembowski JA, Wikenheiser-Brokamp KA, Suarez BK, Whelan AJ, et al: DICER1 mutations in familial pleuropulmonary blastoma. Science 325: 965, 2009.

45. Doros LA, Rossi CT, Yang J, Field A, Williams GM, Messinger Y, Cajaiba MM, Perlman EJ, A Schultz K, Cathro HP, et al: DICER1 mutations in childhood cystic nephroma and its relationship to DICER1-renal sarcoma. Mod Pathol 27: 1267-1280, 2014.

46. Wildi-Runge S, Bahubeshi A, Carret A, Crevier L, Robitaille Y, Kovacs K, Horvath E, Scheithauer BW, Foulkes WD and Deal C: New phenotype in the familial DICER 1 tumor syndrome: Pituitary blastoma presenting at age 9 months. Endocr Rev 32: P1-P777 (Abstract), 2011.
47. Sahakitrungruang T, Srichomthong C,Pornkunwilai S, Amornfa J, Shuangshoti S, Kulawonganunchai S, Suphapeetiporn K and Shotelersuk V: Germline and somatic DICER1 mutations in a pituitary blastoma causing infantile-onset Cushing's disease. J Clin Endocrinol Metab 99: E1487-E1492, 2014.

48. Tajima T, Ma XM, Bornstein SR and Aguilera G: Prenatal dexamethasone treatment does not prevent alterations of the hypothalamic pituitary adrenal axis in steroid 21-hydroxylase deficient mice. Endocrinology 140: 3354-3362, 1999.

49. Haase M, Schott M, Kaminsky E, Lüdecke DK, Saeger W, Fritzen R, Schinner S, Scherbaum WA and Willenberg HS: Cushing's disease in a patient with steroid 21-hydroxylase deficiency. Endocr J 58: 699-706, 2011.

50. Boronat M, Carrillo A, Ojeda A, Estrada J, Ezquieta B, Marín F and Nóvoa FJ: Clinical manifestations and hormonal profile of two women with Cushing's disease and mild deficiency of 21-hydroxylase. J Endocrinol Invest 27: 583-590, 2004.

51. Kozasa T, Itoh H, Tsukamoto $\mathrm{T}$ and Kaziro Y: Isolation and characterization of the human Gs alpha gene. Proc Natl Acad Sci USA 85: 2081-2085, 1988.

52. Aldred MA and Trembath RC: Activating and inactivating mutations in the human GNAS1 gene. Hum Mutat 16: 183-189, 2000.

53. Patten JL, Johns DR, Valle D, Eil C, Gruppuso PA, Steele G, Smallwood PM and Levine MA: Mutation in the gene encoding the stimulatory $\mathrm{G}$ protein of adenylate cyclase in Albright's hereditary osteodystrophy. N Engl J Med 322: 1412-1419, 1990.

54. Williamson EA, Ince PG, Harrison D, Kendall-Taylor P and Harris PE: G-protein mutations in human pituitary adrenocorticotrophic hormone-secreting adenomas. Eur J Clin Invest 25: 128-131, 1995

55. Riminucci M, Collins MT, Lala R, Corsi A, Matarazzo P, Gehron Robey P and Bianco P: An R201H activating mutation of the GNAS1 (Gsalpha) gene in a corticotroph pituitary adenoma. Mol Pathol 55: 58-60, 2002

56. Chesnokova V, Auernhammer CJ and Melmed S: Murine leukemia inhibitory factor gene disruption attenuates the hypothalamo-pituitary-adrenal axis stress response. Endocrinology 139: 2209-2216, 1998.

57. Yano H, Readhead C, Nakashima M, Ren SG and Melmed S Pituitary-directed leukemia inhibitory factor transgene causes Cushing's syndrome: Neuro-immune-endocrine modulation of pituitary development. Mol Endocrinol 12: 1708-1720, 1998.

58. Mathieu ME, Saucourt C, Mournetas V, Gauthereau X, Thézé N, Praloran V, Thiébaud $\mathrm{P}$ and Bouf H: LIF-dependent signaling: New pieces in the Lego. Stem Cell Rev 8: 1-15, 2012.

59. Heutling D, Dieterich KD, Buchfelder $M$ and Lehnert $H$ : Mutation analysis of leukemia inhibitory factor-receptor (LIF-R) in ACTH-secreting pituitary adenomas. Exp Clin Endocrinol Diabetes 112: 458-461, 2004

60. Roussel-Gervais A, Bilodeau S, Vallette S, Berthelet F, Lacroix A, Figarella-Branger D, Brue T and Drouin J: Cooperation between cyclin E and p27(Kip1) in pituitary tumorigenesis. Mol Endocrinol 24: 1835-1845, 2010.

61. Liu NA, Jiang H, Ben-Shlomo A, Wawrowsky K, Fan XM, Lin S and Melmed S: Targeting zebrafish and murine pituitary corticotroph tumors with a cyclin-dependent kinase (CDK) inhibitor. Proc Natl Acad Sci USA 108: 8414-8419, 2011.

62. Georgitsi M, Raitila A, Karhu A, van der Luijt RB, Aalfs CM, Sane T, Vierimaa O, Mäkinen MJ, Tuppurainen K, Paschke R, et al: Germline CDKN1B/p27Kip1 mutation in multiple endocrine neoplasia. J Clin Endocrinol Metab 92: 3321-3325, 2007.

63. Dahia PL, Aguiar RC, Honegger J, Fahlbush R, Jordan S, Lowe DG, Lu X, Clayton RN, Besser GM and Grossman AB: Mutation and expression analysis of the $\mathrm{p} 27 / \mathrm{kip} 1$ gene in corticotrophin-secreting tumours. Oncogene 16: 69-76, 1998. 